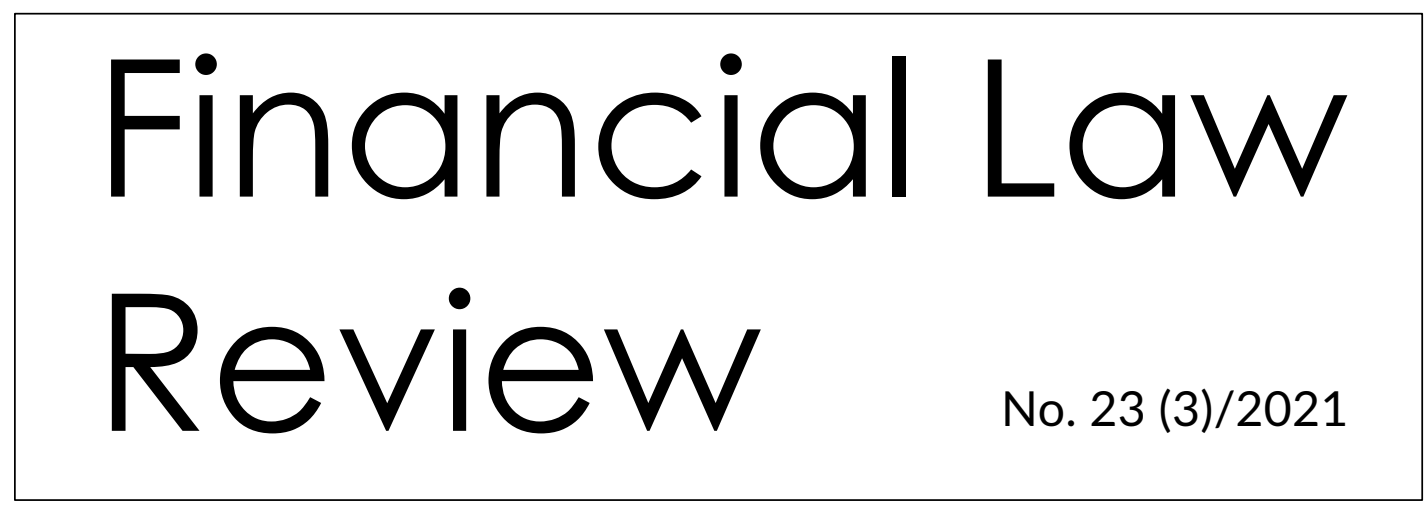

UNIVERSITY OF GDAŃSK • MASARYK UNIVERSITY • PAVEL JOZEF ŠAFÁRIK UNIVERSITY • UNIVERSITY OF VORONEZH

http://www.ejournals.eu/FLR

\title{
PETER RAKOVSKÝ* \\ FINAL REGIME OF THE VALUE ADDED TAX IN THE EUROPEAN UNION AND THE SLOVAK REPUBLIC
}

\begin{abstract}
In this article we introduce and analyse the main legal actions regarding the value added tax final regime legislation and we try to detect the most important measures to fight against tax frauds. The article tries to identify the individual actions that have already entered into force within the European Union countries (the Slovak Republic including) and actions which are in legislative procedure at this moment.
\end{abstract}

Key words: final regime, value added tax, proposal, directive, reverse charge, fraud.

JEL Classification: K34

\section{Introduction}

The main hypothesis of the article is to quantify how the European Union individual laws have shifted the current value added tax system towards a final regime and how the Slovak Republic has implemented these laws. The methods used include abstraction, comparison, analysis, synthesis, induction, deduction, and summarization. If the above hypothesis is

\footnotetext{
* Peter Rakovský, Faculty of Law, Comenius University in Bratislava, the Slovak Republic researcher, address: Šafárikovo námestie č. 6, P.O.BOX 313, 81000 Bratislava, the Slovak Republic. The author specializes in direct and indirect tax regulation, mainly in transfer pricing, VAT and digitalisation. He is a co-author of 2 scientific monographs and author of over 25 scientific papers. At the time of writing, a review of his own scientific monograph on VAT is reviewed by reviewers. Contact email: peter.rakovsky@flaw.uniba.sk, https://orcid.org/0000-0002-5726-3552.
} 
confirmed, we will continue to verify the subsequent partial hypothesis of how these measures can be sufficient and useful to fight against the tax frauds.

This contribution deals with legislative actions of the European Union and the Slovak Republic. However, as is clear, this article may be applicable in all European Union countries due to the fact that individual European Union measures are or will have to be implemented in all member states. The main aim of the contribution is to confirm or disprove the hypothesis used. Up to the date of writing this article, most of the documents relevant for this article are working documents of the European Union. However, the author identified some scientific works regarding partial measures relevant to value added tax and these works have been adopted and implemented into the relevant parts of this article. For example, Danko and Zarska stressed the importance of digitalisation of tax administration [Danko-Zarska 2018], valuation of the sufficiency of the current models of digital economy [Sábo 2020] and the statement of the need that digitalization undoubtedly creates a new set of issues that the science of tax law must address [Hrabčák, Popovič 2020]. In the article we will try to verify whether these opinions and working documents of the European Union are authoritative for the objective pursued and verify the purposed final regime.

The article will be divided into eight parts, introduction and conclusion including. The second part will deal with the main purpose and goal of the final regime of the value added tax. The next parts are divided into the most significant value added frauds that are recognised by the European Union within the member states and legislative measures to tackle and fight tax frauds. We will try to identify whether purposed legislative actions are in line with the proportionality ad subsidiarity principles. The main body of the paper focuses on the de lege lata and de lege ferenda rules, whose main goal in the future is to change the value added tax system as we know it to the European Union wish area, where the taxes are redistributive on the basis of the principle of justice. On the other hand, it must be noted that this work focuses on the value added tax mostly, but in some moments we try to sketch the necessary measures in other relevant areas. In the conclusion we will evaluate our hypotheses and state our conclusions.

The European Union (EU) value added tax system is an asset of the single market; by removing obstacles that distorted competition and prevented the free movement of goods it has greatly facilitated trade in the EU and is still object of the most spectacular change of the tax system of the twentieth century [Bartes 2018: 8]. As a broad-based consumption tax, the value added tax is considered to be one of the most growth-friendly forms of taxation. However, in recent years, the value added tax system has been unable to keep 
pace with the globalisation and digitalisation of the economy ${ }^{1}$. In particular, the current system for the taxation of trade between member states is still particularly based on 25 year old "transitional arrangements". Under these arrangements, domestic transactions and cross-border transactions are subject to two completely different value added tax regimes. In addition, by allowing goods to be purchased cross-border free of value added tax, these arrangements are particularly prone to fraud.

\section{Final regime of the VAT}

Value-added tax (VAT) is Europe's longest-standing consumption tax. In 1967 the commitment was made to establish a definitive VAT system operating within the European Community in the same way as it would within a single country. The need to abolish the fiscal frontiers between member states by the end of 1992 made it necessary to reconsider the way in which trade in goods was taxed in the European Community. The goal was that goods would be taxed in the country of origin, so that the same conditions that apply to domestic trade would also apply to intra-Community trade, perfectly reflecting the idea of a genuine internal market [Proposal for Directive introducing the definitive system for the taxation]. European system of value added tax is based on the principle of fiscal neutrality which presupposes that unless an explicit exception is provided, VAT applies to all business activities and all business entities, thus creating a level playing field for all business entities from a tax point of view. The system is based on the assumption that VAT is borne only by the final consumer, but is paid by the supplier the VAT thus only "flows" through taxable persons without affecting their costs and revenues [Feldek 2020: 35-36].

Final regime would in the end of the day require replacing the current system consisting of an exempt supply in the member state of departure of the goods and a taxed intraCommunity acquisition of goods in the member state of destination by a system of a single supply taxed in and in accordance with the VAT rates of the member state of destination.

1 In this area, Council Directive 2017/2455 amending Directive 2006/112/EC and Directive 2009/132/EC as regards certain value added tax obligations for supplies of services and distance sales of goods has been adopted (to the Slovak legal system implemented through the Act No. $369 / 2018$ Coll.), but the work at digitalisation of VAT system is just beginning. Selective parts of this Directive have also been adopted within the newly approved act, which is not published in the Law Collection yet. Within this act is also Council Directive (EU) 2019/1995 of 21 November 2019 amending Directive 2006/112/EC as regards provisions relating to distance sales of goods and certain domestic supplies of goods and Council Directive (EU) 2018/1695 of 6 November 2018 amending Directive 2006/112/EC on the common system of value added tax as regards the period of application of the optional reverse charge mechanism in relation to supplies of certain goods and services susceptible to fraud and of the quick reaction mechanism against VAT fraud implemented. 
A "destination-based" VAT system means that goods traded across borders are taxed in the country where they are consumed (the destination country) and at the destination country's tax rate, rather than where they are produced (the origin country). As a rule, the VAT will be charged by the supplier who will be able to verify the applicable VAT rate of any member state online by means of a web portal. However, where the person acquiring the goods is a so called certified taxable person [Proposal for a regulation as regards the certified taxable person] (a reliable taxpayer recognised as such by member states), the reverse charge mechanism would apply and the certified taxable person should be liable to VAT on the intra-Union supply. The VAT final system will also be based on the concept of a single registration scheme (One-Stop Shop) for businesses allowing for the payment and deduction of the VAT due [Proposal for Directive introducing the definitive system for the taxation]. The concept of certified taxable person should allow for an attestation that a particular business can globally be considered to be a reliable taxpayer [Proposal for a regulation as regards the certified taxable person]. As we will explain in our article, final regime of VAT will have a couple of advantages. On the other hand, there are a few risks as well, like data protection [Danko-Zarska 2018: 183-189] or high initial costs for small and medium enterprises (SME). However, because of the main purpose of this article, in the following text we will focus only on the further legislative changes and measures.

We have briefly introduced the main ideas and legislative proposals. Now let's have a look at the proposed changes in detail. The modernisation of the existing VAT system will be achieved through a series of gradual steps. The above mentioned communication reports on the actions that have already been taken and provides further details on the steps forward. In the scope of the targeted measures to address fraud, the European Commission (Commission) has launched the development of the so-called transaction network analysis for the exchange and joint processing of targeted VAT data by risk analysis officials of the Eurofisc [Anti-fraud network EUROFISC starts operational work] ${ }^{2}$ network. This new instrument will allow tax authorities to stop fraudulent networks in a simpler, quicker and more secured way [Action Plan on VAT Towards a single EU VAT area - Time to act]. Following this work, on 7 April 2016 the Commission adopted the Action Plan on VAT - Towards a single EU VAT area - Time to decide (VAT Action Plan). The Commission announced, inter alia, its intention to adopt a definitive VAT system for intraUnion cross-border trade based on the principle of taxation in the member state of

2 EUROFISC is a mechanism provided for member states to enhance their administrative cooperation in combating organised VAT fraud and especially carousel fraud. EUROFISC allows for quick and targeted sharing of information between all member states on fraudulent activities. 
destination of the goods in order to create a robust single European VAT area. A legislative proposal for such a simpler and fraud-proof definitive VAT system for intra-Union trade was included in the Commission Work Programme for 2017 [Commission Work Programme 2017].

\section{Basic types of tax frauds related to VAT}

Before we get to the individual improvements leading to the final regime, we consider it important to introduce most usual types of VAT frauds in the Commission's point of view. According to the Commission's opinion, there exist three main types of cross-border frauds most significant across the EU. It is so called i) carousel fraud (or missing trader intraCommunity fraud - MTIC fraud), ii) used car fraud and iii) fraud involving customs procedures 42 and 63 [Does the control of customs procedure 42 prevent and detect VAT evasion?].

MTIC fraud occurs when a fraudster purchases goods or services from another member state free of VAT but then charges VAT when he resells them to the customer; he pays no VAT to the tax authorities (while the customer can deduct it) [Kacaljak 2020:34-35]. The European Court of Auditors and Europol have estimated that MTIC fraud could account for EUR 40 to 60 billion of annual VAT revenue losses and that $2 \%$ of organised crime groups could be behind $80 \%$ of the fraud.

Due to the dual VAT regime applicable to cars ('margin scheme' or normal arrangements), trading in cars is often subject to VAT fraud. The easiest way to commit fraud is to sell recent or new means of transport (for which the whole amount is taxable) as second-hand goods (for which only the margin is taxable).

Lastly, the scheme for importing goods free of VAT (customs procedures 42 and 63), implemented to ease trade where the goods are immediately delivered to a business in another member state, is often abused and the goods are diverted to the black market without VAT having been paid. This type of fraud sometimes occurs with the fraudulent undervaluation of the goods to avoid customs duties. There were 8.5 million import transactions with a VAT exemption in 2015, with a total value of EUR 74 billion [Proposal for regulation as regards measures to strengthen administrative cooperation]. 


\section{Legislative measures to tackle and fight against tax frauds}

Regulation No 904/2010 lays down the conditions under which the member states' competent authorities cooperate with each other and with the Commission to ensure compliance with VAT rules within the single market. The VAT Action Plan seeks to bolster VAT administrative cooperation instruments, in particular Eurofisc, as a means of strengthening trust between tax authorities before the final VAT regime comes into play. Pending that, such measures will also help contain cross-border fraud [Measures to strengthen administrative cooperation in the field of value added tax regulation].

The initiative against tax frauds goes hand in hand with other VAT initiatives and would play an important role in securing the success of the most ambitious proposal implementing the final VAT regime. Additionally, MTIC fraud is one of the ten crime areas that Europol and the Council have identified as top priorities for the EU for the period of 2018-2021. It is also relevant and important to implement other legislative measures. One of them is the Directive (EU) 2017/1371 of the European Parliament and of the Council of 5 July 2017 on the fight against fraud to the Union's financial interests by means of criminal law, which covers serious EU-wide VAT fraud and Council Regulation (EU) 2017/1939 of 12 October 2017 implementing enhanced cooperation on the establishment of the European Public Prosecutor's Office. This independent and decentralised EU body will be responsible for investigating and prosecuting crimes against the EU budget, such as fraud, corruption, or cross-border VAT fraud above EUR 10 million. In these days, it is not possible to evaluate the effect of these measures due to their recent entry into force, but we expect them to be highly effective in the fight against fraud.

Council Directive (EU) 2018/1695 of 6 November 2018 amending Directive 2006/112/EC on the common system of value added tax as regards the period of application of the optional reverse charge mechanism in relation to supplies of certain goods and services susceptible to fraud and of the quick reaction mechanism against VAT fraud amends the Council Directive 2006/112/EC of 28 November 2006 on the common system of value added tax (VAT directive) in such a way that until 30 June 2022, member states may provide that the person liable for the payment of VAT is the taxable person to whom any of the following supplies are made. In such cases, the person liable for payment of VAT on supplies is the taxable person to whom the supply is made (the 'reverse charge mechanism') in order to promptly tackle the above mentioned problem of the missing trader fraud in intra-Community trade. A member state may, in cases of imperative urgency, designate the recipient as the person liable to pay VAT on specific supplies of 
goods and services as a quick reaction mechanism special measure to combat sudden and massive fraud liable to lead to considerable and irreparable financial losses [Directive as regards the period of application of the optional reverse charge mechanism]. Jadwiga Glumińska-Pawlic states that while it is true that goods covered by this mechanism cannot be used for fraud based on "empty" invoices, this cannot be said of other areas, which are easily affected. „This in turn means that revenues from hitherto taxable market segments decrease, as given the absence of an output tax burden with a simultaneous right to an input tax deduction (equivalent of the $0 \%$ rate), bogus supplies covered by this mechanism make it possible to create a surplus of input tax over output tax and enable a VAT return fraud without having to recourse to feign an intra-Community supply of goods" [Glumińska-Pawlic 2019: 31].

\section{Compliance with the subsidiarity and proportionality principle}

According to the principle of subsidiarity, as set out in Article 5(3) of the Treaty on European Union ${ }^{3}$, action at the EU level may only be taken if the envisaged aims cannot be achieved sufficiently by the member states alone and can therefore, by reason of the scale or effects of the proposed actions, be better achieved by the EU.

VAT rules for cross-border Union trade can, by their nature, not be decided by individual member states since, inevitably, more than one-member state is involved. Moreover, VAT is a tax harmonised at the EU level and therefore any initiative to introduce the definitive VAT system for cross-border supplies of goods requires a proposal by the Commission to amend the VAT Directive.

As regards the provisions to harmonise and simplify rules within the current VAT system, they have unanimously been requested by the member states, which demonstrates that action at the EU level is likely to be more effective since action at national level has not proven to be sufficiently successful.

Proposal for Directive introducing the definitive system for the taxation, as far as the introduction of the definitive system for intra-Union B2B trade is concerned, is consistent with the principle of proportionality, i.e. it does not go beyond what is necessary to meet the objectives of the EU Treaties, in particular the smooth functioning of the single market.

\footnotetext{
3 "Under the principle of subsidiarity, in areas which do not fall within its exclusive competence, the Union shall act only if and in so far as the objectives of the proposed action cannot be sufficiently achieved by the Member States, either at central level or at regional and local level, but can rather, by reason of the scale or effects of the proposed action, be better achieved at Union level".
} 
As with the subsidiarity test, it is not possible for member states to address problems such as fraud or complexity without a proposal to amend the VAT Directive.

As regards the proposed improvements to the current system, they are targeted and limited to a restricted number of VAT rules which have proven difficult to apply in a systematic and uniform way and which have created problems for taxable persons. According to that, we can conclude that the proposals of legislative changes covering VAT final system are in line with the subsidiarity and proportionality principles.

\section{Exchange of information}

"The Paradise Papers have again shown how some are taking advantage of lax application of EU VAT rules to get away with paying less VAT than others. And we know that VAT fraud can be a source of financing for criminal acts, including terrorism. Combating this requires far more effective information-sharing than currently exists between the competent national authorities - and today's proposals will make that happen" [Pierre Moscovici, Commissioner for Economic and Financial Affairs, Taxation and Customs]. The exchange of information is necessary not only in one separate country, but must also work on a broader level to tackle tax frauds. Within the EU, most of the legislative activities focus on direct taxes. Council Regulation (EU) No 904/2010 of 7 October 2010 on administrative cooperation and combating fraud in the field of value added tax lays down the conditions under which the competent authorities in the member states responsible for the application of the laws on VAT are to cooperate with each other. To that end, it lays down rules and procedures to enable the competent authorities of the member states to cooperate and to exchange with each other any information that may help to effect a correct assessment of VAT, monitor the correct application of VAT, particularly on intraCommunity transactions, and combat VAT fraud. In particular, it lays down rules and procedures for member states to collect and exchange such information by electronic means [Regulation (EU) No 904/2010 of 7 October 2010 on administrative cooperation and combating fraud in the field of value added tax]. Moreover, exchange of information has more advantages, in different areas as well. Measures to fight against the grey economy and tax frauds are also connected with the fight against anti-money laundering and financing terrorism [Daudrikh 2020: 158-164 and Daudrikh 2020: 384-400] which is unquestionably connected with the bank system and the process of globalization and the strong interconnectedness of national economies, particularly in the area of financial systems and foreign trade [Heseková 2016: 10]. 
While the tax authorities of member states already exchange some information on business and cross-border sales on that basis, this cooperation relies heavily on the manual processing of information. At the same time, VAT information and intelligence on organised gangs involved in the most serious cases of VAT fraud are not shared systematically with EU enforcement bodies. Finally, a lack of investigative coordination between tax administrations and law enforcement authorities at national and the EU level mean that this fast-moving criminal activity is not currently tracked and tackled quickly enough [Fair Taxation: Commission proposes new tools to combat VAT fraud]. In addition, exchange of information is a significant measure in both indirect and direct taxes and these actions must co-operate. Moreover, digitalised economy would be very positive in the area of direct taxes, income tax especially. Some authors also note that current rules are also not sufficient enough for current models of digital economy [Sábo 2020: 65] and that digitalization undoubtedly ... creates a new set of issues that the science of tax law must address [Hrabčák, Popovič 2020: 53] in direct taxes as well.

\section{De lege lata and de lege ferenda rules - final system}

As we have stated above, the Commission opted for taxation rules according to which, for intra-Union cross-border supplies of goods, the supplier would charge the VAT to his customer at the rate of the member state of arrival of the goods. The VAT would be declared and paid in the member state where the supplier is established via a one-stopshop mechanism. Moreover, during the first step of the final VAT system and as an exception to this general principle, if the customer is certified as a compliant business by its tax authorities (a possibility also opened to SMEs), this customer would continue to be liable for the VAT on goods purchased from other member states as is currently the case. Even though the Slovak legal system already knows the equivalent of the institute of certified person ${ }^{4}$, in the following text we will present its proposed legal regulation valid for the whole EU.

Similar to domestic transactions, in intra-Union transactions in goods, the supplier would charge the VAT due (one of the member states of destination of the goods) to his customer. However, if his customer is a certified taxable person, he will not charge the VAT due to him. The customer will, as is currently the case, self-assess the VAT due in his domestic VAT return. For the purpose of these changes, the concept of "intra-Union

\footnotetext{
4 In Sec. 53d of Act No. 563/2009 Coll. Tax Procedural Code as amended, Slovak tax system recognizes the so called tax reliability index which rates Slovakia taxpayers according to the level of fulfilment of tax obligations and which provides some advantages to reliable taxpayers.
} 
supply of goods" will be introduced and the notion of "intra-Community acquisition of goods" will be abolished.

Further, the certified taxable person concept will be one of the essential elements of the first step of the definitive VAT system for intra-Union B2B trade. That definitive system will replace, by one taxable supply of goods located for VAT purposes in the member state of destination (the so-called intra-Union supply of goods), the current transitional arrangements which entail an exempt supply of goods in the member state of departure and a taxed intra-Community acquisition in the member state of destination, for which the acquirer is the person liable to VAT. The certified taxable person concept will allow for a gradual implementation of the definitive VAT system because, in the first step of that system, reverse charge (i.e. liability to VAT of the acquirer and not of the supplier, which gives rise in practice to a situation similar to what exists today under the transitional arrangements) will apply where the acquirer, in case of intra-Union supplies, is a certified taxable person. The justification is that no fraud should occur as a result of VAT not being charged on intra-Union supplies made for a certified taxable person, as the certified taxable person by definition is a reliable taxpayer [Proposal for Directive introducing the definitive system for the taxation]. Since the certified taxable person status entails VAT reporting and payment obligations, non-taxable persons will not be eligible. For the same reason, the proposal excludes flat-rate farmers, exempt SMEs, other taxable persons exempt without the right to deduct and occasional taxable persons from the possibility of obtaining the certified taxable person status. However, any SME not applying the exemption scheme will be able to apply for the certified taxable person status under the same conditions as any other taxable person. It is therefore consistent with the EU SME policy as set by the Small Business Act (SBA) [Think Small First - A Small Business Act].

The current transitional [Proposal for Directive introducing the definitive system for the taxation] arrangements are further based on the obligation for the supplier to submit a recapitulative statement (the so-called VIES listing which includes the VAT identification number of the acquirer). From Slovakia legal point of view, VAT identification number of the acquirer (assigned in another member state to the supplier) is a material condition for exemption for the supply of goods from origin country to another member state. This information is, via the VIES system, accessible for the tax authorities of the member state of the acquirer, which are thus informed of the arrival in its territory of goods that are normally subject to a taxed intra-Community acquisition. The acquirer has to declare this intra-Community acquisition in his VAT return and the tax authorities have the possibility to cross-check this declaration with data in the VIES system. The VIES listing has therefore 
been a crucial component of the VAT system since the abolition of the fiscal borders and the corresponding disappearance of the customs documentation.

Without correct information from the VIES system, the tax authorities of the member states are not duly informed of the arrival of untaxed goods in their territory and have solely to rely on what their taxable persons declare. Nevertheless, if the listing is not filled in as regards a supply, this can give rise to penalties but not to the rejection of the exemption as such.

In the second legislative step of the final VAT system, taxation would cover all crossborder supplies of goods and services (and therefore the supplier, and not the customer, would be liable for the VAT on all goods and services purchased from other member states) so that all supplies of goods and services within the single market, either domestic or cross-border, will be treated the same way [Communication to the Action Plan on VAT].

On the other hand, the Council's conclusions and discussions with the member states on the VAT Action Plan showed a need to introduce certain short-term improvements to the current VAT system ("quick fixes"). Those four quick fixes have been introduced together with the legal cornerstones of the final VAT system [Council on Improvements to the current EU VAT].

Following this work, the Council in its conclusions stated that, while the Commission is working on the final VAT system for intra-Union trade, improvements to the current VAT system should be made in the meantime. In addition, the presented proposal introduces the cornerstones of the final system for intra-Union B2B trade. In this context, the Council requested amendments in four areas [Proposal for Directive introducing the definitive system for the taxation].

- VAT identification number: The Council invited the Commission to present a legislative proposal aimed at making the valid VAT identification number of the taxable person or non-taxable legal person acquiring the goods, allocated by a member state other than that in which dispatch or transport of the goods began, an additional substantive condition for the application of the exemption in respect of an intra-Community supply of goods ${ }^{5}$.

- Chain transactions: The Commission was invited by the Council to propose uniform criteria and appropriate legislative improvements which would lead to increased legal certainty and harmonised application of VAT rules when determining the VAT

\footnotetext{
${ }^{5}$ As we have mentioned before, this measure has been adopted by Slovakia in Sec. 43 of the Act. No 222/2004 Coll. on value added tax as amended.
} 
treatment of chain transactions, including triangular transactions. Chain transactions, which are considered within the remit of this proposal, have to be understood as successive supplies of the same goods where the goods supplied are subject to a single intra-Community transport between two member states. In this situation, according to the case-law of the Court of Justice [Judgment of 6 April 2006, Emag Handel, C-245/04, ECLI:EU:C:2006:232.], the transport is to be attributed to one supply within the chain so as to determine to which of the transactions the exemption for intra-Community supplies should be applied in accordance with Article 138 of the VAT Directive. Where the transport has been made by or on behalf of one of the intermediate suppliers in the chain, rules are proposed whereby that transport will be ascribed (i) to the supply made for that intermediate supplier if he is, for VAT purposes, identified in a member state other than the member state of supply and has communicated the name of the member state of arrival of the goods to his supplier; (ii) to the supply made by the intermediate supplier to the next operator in the chain, where any of the two conditions mentioned in (i) is not met. The rules, and the legal certainty they allow, apply only where the intermediate supplier and the taxable person who supplied the goods to him are both certified taxable persons. No rule of this kind is needed where the transport is made on behalf of the first supplier in the chain (in which case the transport can only be ascribed to the first supply) or on behalf of the last taxable person in the chain (in which case the transport can only be ascribed to the supply made for that taxable person).

- Call-off stock: The Council invited the Commission to propose modifications to the current VAT rules in order to allow simplification and uniform treatment for call-off stock arrangements in cross-border trade. To this effect, 'call-off stock' refers to the situation where a vendor transfers goods to a warehouse at the disposal of a known acquirer in another member state and that acquirer becomes the owner of the goods upon calling them off the warehouse [Council Directive (EU) 2018/1910 of 4 December 2018 amending Directive 2006/112/EC] ${ }^{6}$. In domestic relationships, the use of this model does not create specific problems but issues arise when supplier and acquirer are situated in different member states. Under the

\footnotetext{
${ }^{6}$ In order to meet the request of the Council, amendments to the VAT Directive have been proposed for the three first areas. Such a regulation has been adopted to the national legislation through the Council Directive (EU) 2018/1910 of 4 December 2018 amending Directive 2006/112/EC as regards the harmonisation and simplification of certain rules in the value added tax system for the taxation of trade between member states also with the Methodical guidelines of the call off stock implementation.
} 
current VAT rules, a business transferring own goods to another member state in order to constitute a stock for a customer is deemed to have made a VAT exempt supply of goods in the member state of departure. The arrival of the goods gives rise to an intra-Community acquisition made by the business that transferred the goods which is subject to VAT in that other member state. The business that has transferred the goods is obliged, as a rule, to be identified for VAT purposes in the member state of arrival in order to be able to declare the intra-Community acquisition in its VAT return. When the goods are taken out of the stock and delivered to the acquirer a second supply occurs, the place of supply of which is the member state in which the stock is situated [Proposal for Directive introducing the definitive system for the taxation].

- Proof of intra-Community supply: The Council invited the Commission to explore possibilities for a common framework of recommended criteria for the documentary evidence required to claim an exemption for intra-Community supplies. [State Aid SA.52194 (2018/FC)]?.

As we can see, there are many measures that have already been adopted and there are more to be implemented in the near future. Directive (EU) 2020/284 amends VAT Directive, introducing certain requirements on payment service providers to keep records of cross-border payments related to e-commerce. The data will then be made available to national tax authorities under strict conditions, including those related to data protection. These requirements apply from 1 January 2024.

Another Directive (EU) 2020/285 introduces simplified rules to reduce the administrative burden and compliance costs for small businesses and to create a more advantageous tax environment to help them grow and trade across borders more efficiently. Small businesses will be able to qualify for simplified VAT compliance rules where their annual turnover remains below a threshold set by the EU country concerned, which cannot be higher than EUR 85,000. Under certain conditions, small businesses from other EU countries, which do not exceed this threshold, will also be able to benefit from the simplified scheme, if their total annual turnover in the whole of the EU does not exceed EUR 100,000. These new rules apply from 1 January 2025 [The EU's common system of value added tax (VAT)].

\footnotetext{
7 The fourth area required a modification of the Council Implementing Regulation (EU) No 282/2011 of 15 March 2011 laying down implementing measures for Directive 2006/112/EC on the common system of value added tax.
} 
The VAT e-commerce package - Directives (EU) 2017/2455 and (EU) 2019/1995 both amending VAT Directive introduced new simplifications for companies carrying out crossborder sales of goods or service. It ensures that VAT on such supplies is paid correctly to the EU country of the customer, in line with the principle of taxation in the EU country of destination. The first measures entered into force in 2015 and covered only telecommunications, broadcasting and electronic (TBE) services. Businesses providing business-to-consumer (B2C) supplies of TBE services in the EU can now declare and pay VAT in a simplified system (Mini One Stop Shop - MOSS) [Modernising VAT for crossborder e-commerce].

\section{Conclusion}

Member states are the subjects which are primarily responsible for VAT management, collection and checks. However, VAT fraud is often linked to cross-border transactions within the single market or involves traders established in other member states than the one where the tax is due. However, this problem must be addressed individually by each member state. It adversely affects how the single market functions and causes serious losses to the EU budget. Modernising the VAT system and adapting it to the challenges posed by the fight against fraud is key for the future of our single market. The reform of the current VAT system should contribute to the development of the digital single market and complement the agenda set by the EU for a fairer and more efficient corporate tax system in the EU. In this context, it is both necessary and urgent to keep progressing on the path towards an EU-wide VAT system that can boost jobs, growth, investment and competitiveness and is fit for an increasingly digitalised economy.

After our analysis, we believe that we have proved that measures of the EU in the VAT are and will be a sufficient way to reach the place in the world where the taxes are redistributive on the basis of the principle of justice. Based on that, we can confirm our main hypothesis that EU individual laws have shifted the current VAT system towards a final regime and the Slovak Republic is following these steps. As a partial conclusion we can state that the above mentioned quick fixes together with the proposal for Directive introducing the definitive system for the taxation and Communication to the Action Plan on VAT together with Directive on the fight against fraud to the EU financial interests by means of criminal law and Council Regulation on administrative cooperation and combating fraud in the field of VAT represent the main legal actions in the way of the VAT final regime up to date. The aim which we set out in this paper was to analyse whether 
these actions are able to fight against tax frauds. We can confirm this partial hypothesis as well. We have identified a significant number of acts and actions which can represent the opinion of the whole EU to make a cooperative way as a team. The European Union individual laws have shifted the current value added tax system towards a final regime and the Slovak Republic has implemented these laws and these measures can be sufficient and useful to fight against the tax frauds.

Transitional arrangements in the VAT Directive regarding intra-EU transactions in goods between businesses resulted in revenue losses for member states of about EUR 50 billion due to missing trader intra-Community fraud, which finds its roots in the endemic weakness of such system that allows for goods being bought cross-border VAT-free and complexity causing higher costs for businesses trading cross-border compared to businesses trading only domestically due to additional obligations for cross-border traders and divergent application by member states of VAT rules. Without action at the EU level, solutions would continue to be fragmented and have limited benefits. According to that, we can conclude that the proposals of legislative changes covering VAT final system are in line with the subsidiarity and proportionality principles. Definitive arrangements for the taxation of intra-EU trade are meant to make the EU VAT system more robust by addressing its endemic weakness and simpler by addressing its complexities and to provide a level playing field for businesses whether engaged in domestic or cross-border transactions. 


\section{References}

Bartes, R.: Evolution of VAT, Financial Law Review, no. 12 [4], 2018

Danko, M - Zarska, P.: The Digital tax system in the light of GDPR, Bratislava Law Review, no. 2 [2], 2018

Daudrikh, Y.: Economic sanctions: concept, types and process of imposition, Mezinárodní Masarykova konference pro doktorandy a mladé vědecké pracovníky, Hradec Králové: Magnanimitas akademické sdružení, no 1, 2020

Daudrikh, Y.: Implementation of V. AML Directive into national legislation in the territory of the Slovak Republic, Strategies, models and technologies of economic systems management in the context of international economic integration, Riga: Institute of Economics of the Latvian Academy of Sciences no. 2, 2020

Feldek, M.: Guarantee for the value added tax, Financial Law Review, 2020, no. 20 [2], 2018

Glumińska-Pawlic, J.: Prevention of the Loss of VAT Revenues - An Attempt at Evaluation of New Legal Instruments, Financial Law Review, no. 16 [4], 2019

Heseková, S.: Recentné zmeny v bankovej oblasti v snahe o jej optimálne fungovanie, Aktuálne otázky finančného práva a trendy $v$ jeho výučbe. Zborník príspevkov zo spoločného stretnutia katedier finančného práva Právnických fakúlt univerzít Slovenskej republiky a Českej republiky, Bratislava, 21. - 22.4.2016, 2016

Hrabčák, L - Popovič, A.: On certain issues of digital service taxes, Financial Law Review, no.17 [1], 2020

Kačaljak, M.: Podvod na DPH a zneužitie práva v oblasti DPH v právnej doktríne a aplikačnej praxi na Slovensku, bulletin Slovenskej komory daňových poradcov, no. [1], 2020

Sábo, J.: Taxation of Digital Services from International Tax Law Perspective, Financial Law Review, no. 20 [4], 2020

\section{Legal Acts}

Act of 1 December 2009 on Tax Procedural Code as amended (No. 563/2009 Coll.)

Act of 6 April 2004 on value added tax as amended (No. 222/2004 Coll.)

Council Directive (EU) 2017/1371 of the European Parliament and of the Council of 5 July 2017 on the fight against fraud to the Union's financial interests by means of criminal law

Council Directive (EU) 2017/2455 amending Directive 2006/112/EC and Directive 2009/132/EC as regards certain value added tax obligations for supplies of services and distance sales of goods

Council Directive (EU) 2018/1695 of 6 November 2018 amending Directive 2006/112/EC on the common system of value added tax as regards the period of application of the optional reverse charge mechanism in relation to supplies of certain goods and services susceptible to fraud

Council Directive (EU) 2018/1910 of 4 December 2018 amending Directive 2006/112/EC as regards the harmonisation and simplification of certain rules in the value added tax system for the taxation of trade between member states

Council Directive (EU) 2019/1995 of 21 November 2019 amending Directive 2006/112/EC as regards provisions relating to distance sales of goods and certain domestic supplies of goods

Council Regulation (EU) 2017/1939 of 12 October 2017 implementing enhanced cooperation on the establishment of the European Public Prosecutor's Office

Council Regulation (EU) 282/2011 of 15 March 2011 laying down implementing measures for Directive 2006/112/EC on the common system of value added tax

Council Regulation (EU) $904 / 2010$ as regards measures to strengthen administrative cooperation in the field of value added tax

\section{Court Rulings}

European Court of Justice [Judgment of 6 April 2006, Emag Handel, C-245/04, ECLI:EU:C:2006:232].

\section{Other Official Documents}

European court of auditors: does the control of customs procedure 42 prevent and detect vat evasion? 
Available at:

https://www.eca.europa.eu/Lists/News/NEWS1112_13/NEWS1112_13_EN.PDF, accessed: $18^{\text {th }}$ January 2021

European Union: Amended proposal for a Council regulation amending Regulation (EU) No $904 / 2010$ as regards measures to strengthen administrative cooperation in the field of value added tax

Available at: https://eur-lex.europa.eu/legal-

content/EN/TXT/HTML/?uri=CELEX:52017PC0706\&from=SK, accessed:18 $8^{\text {th }}$ January 2021

European Union: Communication from the commission to the European parliament, the council, the European economic and social committee and the committee of the regions. Commission Work Programme 2017. Delivering a Europe that protects, empowers and defends

Available at: https://eur-lex.europa.eu/legal-

content/EN/TXT/HTML/?uri=CELEX:52016DC0710\&from=SK, accessed:18 $8^{\text {th }}$ January 2020

European Union: Communication from the Commission to the European parliament, the Council and the European economic and social committee On the follow-up to the Action Plan on VAT towards a single EU VAT area - Time to act COM/2017/0566 final

Available at: https://eur-lex.europa.eu/legal-

content/en/TXT/?uri=CELEX\%3A52017DC0566, accessed:18 ${ }^{\text {th }}$ December 2020

European Union: Communication from the Commission to the Council, the European Parliament, the European Economic and Social Committee and the Committee of the Regions - "Think Small First" - A "Small Business Act" for Europe

Available at: https://eur-lex.europa.eu/legal-

content/EN/TXT/?uri=CELEX\%3A52008DC0394, accessed:18 ${ }^{\text {th }}$ January 2021

European Union: Commission Staff Working Document executive Summary Of The Impact Assessment. Accompanying the document. Proposal for a Council Directive amending Directive 2006/112/EC as regards harmonising and simplifying certain rules in the value added tax system and introducing the definitive system for the taxation of trade between Member States

Available at: https://eur-lex.europa.eu/legal-

content/EN/TXT/HTML/?uri=CELEX:52017SC0326\&from=SK, accessed:18 ${ }^{\text {th }}$ January 2021

European Union: Council conclusions of 8 November 2016 on Improvements to the current EU VAT rules for cross-border transactions

Available at: http://data.consilium.europa.eu/doc/document/ST-14257-2016-INIT/en/pdf, accessed: $19^{\text {th }}$ January 2021

European Union: Modernising VAT for cross-border e-commerce

Available at: https://ec.europa.eu/taxation_customs/business/vat/modernising-vat-crossborder-ecommerce_en accessed: $17^{\text {th }}$ January 2021

European Union: Proposal for a Council Directive amending Directive 2006/112/EC as regards harmonising and simplifying certain rules in the value added tax system and introducing the definitive system for the taxation of trade between Member States

Available at: https://eur-lex.europa.eu/legal-

content/EN/TXT/HTML/?uri=CELEX:52017PC0569\&from=SK, accessed: 12 $2^{\text {th }}$ January 2021

European Union: Proposal for a Council regulation amending Regulation (EU) No 904/2010 as regards the certified taxable person

Available at: https://eur-lex.europa.eu/legal-

content/EN/TXT/HTML/?uri=CELEX:52017PC0567\&from=SK, accessed: 11 January 2021

European Union: Proposal for a Council Directive amending Directive 2006/112/EC as regards harmonising and simplifying certain rules in the value added tax system and introducing the definitive system for the taxation of trade between Member States

Available at: https://eur-lex.europa.eu/legal-

content/SK/TXT/?uri=CELEX\%3A52017PC0569, accessed: 20 January 2021

European Union: The EU's common system of value added tax (VAT)

Available at: https://eur-lex.europa.eu/legal-

content/EN/TXT/HTML/?uri=LEGISSUM:I31057\&from=SK, accessed: $18^{\text {th }}$ January 2021

European Commission: Taxation and Customs Union. Taxation: Anti-fraud network. EUROFISC starts operational work

Available at: https://ec.europa.eu/taxation_customs/sites/taxation/files/docs/body/201102-07_eurofisc_pressrelease_en.pdf, accessed: 18 ${ }^{\text {th }}$ February 2021 
Slovak republic: Methodical guidelines of the call off stock implementation

Available at:

https://www.financnasprava.sk/_img/pfsedit/Dokumenty_PFS/Zverejnovanie_dok/Dane/ Metodicke_pokyny/Nepriame_dane/2019/2019.12.31_MP_call_off_stock.pdf, accessed: $18^{\text {th }}$ February 2021

\section{Internet Resources}

Pierre Moscovici: Commissioner for Economic and Financial Affairs, Taxation and Customs Available at: https://ec.europa.eu/commission/presscorner/detail/en/IP 17 4946, accessed: $17^{\text {th }}$ February 2021

European Commission: Fair Taxation: Commission proposes new tools to combat VAT fraud Available at: https://ec.europa.eu/commission/presscorner/detail/en/IP_17_4946, accessed: $1^{\text {st }}$ February 2021 